DE DE GRUYTER OPEN
Journal of Intercultural Management

Vol. 5, No. 4, December 2013, pp. 35-47

DOI 10.2478/joim-2013-0025

Justyna Fijałkowska

University of Social Sciences

Monika Sobczyk

University of Social Sciences

\title{
Integrated Reporting as a Cross-border Communication Tool for Business - a Fad or a Sign of Times? ${ }^{1}$
}

\begin{abstract}
A model of business communication currently used by companies, based on the financial statements and a number of satellite different themed reports, turns out to be unsatisfying towards high stakeholders' demands for information. Stakeholders expect environmental, social and corporate governance indicators enclosed in the financial and non-financial information, in a form that provides a complete, consistent, clear, comparable and reliable picture of the corporates' achievements. Therefore, in this article we analyze whether the Integrated Report (IR) could become a cross-border communication tool of business, which would satisfy the internal and external global environment needs. For this purpose, in the light of the differences in understanding of business responsibility for society between countries on each side of the Atlantic, the "pros" and "cons" of Integrated Reports are considered and the willingness of the business environment on this new form of communication is examined.
\end{abstract}

Keywords: Business communication, Integrated Report, implications of integrated reporting

\section{Introduction}

A widely and rapidly available information is a sign of our times. Accordingly, the transparency of companies in all aspects of their business is now an

1 Financial support acknowledged to the research grant „Integrated reporting - New model of performance communications, sustainable development and responsibility as a challenge for Polish companies", National Center of Science (Poland), DEC-2011/01/B/HS4/04993. 
essential requirement of the market. The activities of companies beside financial consequences have also social and environmental dimension. Companies strive to communicate it throughout financial statements providing mainly financial information and by publishing satellite reports i.e. Management Commentary, Intellectual Capital Statement, Governance and Remuneration, Environmental Report or Sustainability Report, which disclose also the non-financial information on a business approach to the environment and to the society. In other words, these reports are a tool for communication of environmental, social and governance (ESG) issues, which all together state for corporate social responsibility (CSR). It turns out, however, that these reports are only partially able to meet the information requirements of stakeholders. Several different business reports, indeed, present the activities of corporations in different sections, but information that they contain is incomplete and inconsistent. Without more complete and comprehensive information neither management, nor investors are in a position of effective decision making. In response to the information needs the concept of Integrated Reporting was implemented.

Integrated Reporting means a holistic approach enabling stakeholders to understand how the organization operates. Integrated Report reveals the relationship between financial and non-financial (social, environmental and corporate governance, which constitute the social responsibility) aspects of the organization's activities and their results.

Due to the enormous cultural, organizational and industrial diversity of companies each of these may take responsibility for its impact on the society and the environment in a different way and extend [Sobczyk M., 2013, p. 351]. It is argued that national differences in CSR can be explained by historically grown institutional frameworks that shape "national business systems" [Whitley R., 1997, pp. 173-186]. Particularly large differences between the United States and Europe are characterized and explained by Matten and Moon. They argue that "U.S.-style CSR has been embedded in a system that leaves more incentive and opportunity for corporations to take comparatively explicit responsibility. European CSR has been implied in systems of wider organizational responsibility that have yielded comparatively narrow incentives and opportunities for corporations to take explicit responsibility" [Matten D., Moon J., 2008, p. 409]. Thus, divergence in the form and scope of the presentation of information about CSR is obvious and the process and way of CSR communication should be harmonized globally. However, it is worth stressing that organizational culture, which is strongly influenced by national culture [Sułkowski, 2009]also shapes CSR practices.

The aim of this article is to present the benefits and challenges of Integrated Reporting that may determine its success in business environment. We 
shortly present the development of the concept of CSR communication in the form of Integrated Reports and try to define the place of these report in the current business practice. We focus also on the analysis of regulators and nongovernmental organizations involvement in the area of extended reporting.

\section{Materials \& Methods}

This work is based on the normative research method according to the statement of Ijiri [1975], that the purpose of the normative approach is to emphasize those areas where changes are most needed and where they are feasible. It is assumed that reporting process of companies needs improvements towards integrated reporting that should become one of the main areas of interest of today's management and accounting.

\section{Current state of knowledge}

CSR has its roots in the early social accounting concept, which emerged at the turn of the 50s and 60s of the twentieth century in the United States and resulted directly from this period's specific social conditions and ideological crisis, which prolonged duration required the use of innovative and radical ways of it overcoming.

Social Responsibilities of the Businessman of 1953 by HR Bowen [1953] could be considered as the first significant publication of the CSR. At that time the discussion on the creation of an internal and external reporting system embracing social responsibility was initiated. Accountability became its basis, which includes responsibility for the implemented activities and for providing the settlement of these actions. Since then, practitioners have started to make the first attempts in the implementation the social responsibility into business strategy and in measurement of their costs and effects, as well as in their reporting, creating this way a new level of accounting - social accounting. One of the first authors of publications about the importance of accounting for CSR were Epstein, Flamholtz and McDonough [1977], and Gordon [1978]. The need for extending the traditional model of business reporting is highlighted by Gray [1990], Guthrie and Parker [1989; 1990], Roberts [1992], Gray, Bebbington and Walters [1993], Deegan and Rankin [1997], Mathews [1997], Cordazzo [2007]. With regard to the activities regarding social responsibility, CSR report has become the primary way of communicating. It should "make a business dialogue with the environment, and the message should be complete, reliable, useful and comparable from period to period" [Fijałkowska J., 2012, p. 148].

Integrated Reporting has been the subject of literature studies for almost 20 years. In 1995 Eccles [Eccles, R.G. and Mavrinac, S., 1995] presented results of his research confirming market interest in nonfinancial information. Then, in two books [Eccles et al., 2001; DiPiazza S.A. and Eccles R.G., 2002] further evidence on 
the need to supplement financial reporting with information on non-financial factors that were leading indicators of financial results was provided together with the indications how corporate reporting could be improved. In 2010 Eccles and Krzus [2010] showed that "Integrated Reporting" is an important concept of our times. According to Eccles' definition [2011], Integrated Reporting "is reporting in a single document the material measures of financial and nonfinancial (i.e. environmental, social and governance) performance and their relationships to each other (...), establishes the discipline for integrated internal management of financial and non-financial performance. It is also the best way to report on a sustainable strategy".

Publication of this book coincided with the date of the first Integrated Report - Southwest Airlines One Report disclosure and that was an evidence that the idea of Integrated Reporting had popped up simultaneously in academic theory and practice independently of each other.

While there have been significant advances in CSR reporting over recent years, no single body has so far brought all the different reporting pillars together in a single, mandatory, fully integrated and globally endorsed framework. This is the ambition of the International Integrated Reporting Committee (IIRC), which predecessors were „Accounting for Sustainability” and Global Reporting Initiative.

In 2004 HRH The Prince of Wales established a project called „Accounting for Sustainability" (A4S) which brings together the finance and accounting community from business, government, academia and the capital markets. A4S's work focuses on ways to integrate measures of environmental health, social well-being and economic performance to provide a 'future-proofed' framework for decision making and build the capacity needed to take action. Its purpose is to assist in ensuring that the sustainable development would not only be discussed, but also embedded in organizations, to achieve a common approach in creating and implementing sustainable development strategies, to promote the idea of turning this strategy into the main organizational strategy and to incite to recognize information about sustainability in mainstream business reports.

The Global Reporting Initiative (GRI) is a non-profit multi-stakeholder, network-based organization. It developed a widely worldwide used comprehensive Sustainability Reporting Framework (included the Reporting Guidelines, Sector Guidelines and other resources, called The G3.1 Guidelines) which enables all interested organizations to measure and report four key areas of their sustainability: economic, environmental, social and governance performance to the greater organizational transparency.

IIRC is formed by financial standard setters, securities regulators and sustainability standard setters with representatives from companies, 
investors and civil society, among them academics, whose mission is to create a globally accepted integrated reporting framework which brings together financial, environmental, social and governance, prospective and retrospective information in a clear, concise, consistent and comparable format to meet the needs of a more sustainable, global economy. In 2011, after a series of successful meetings around the globe resulting in the development of Integrated Reporting through regional roundtables, IIRC launched a discussion paper Towards Integrated Reporting. Communicating Value in the 21st Century in which the idea of Integrated Reporting was widely announced. In this work, the need to prepare an Integrated Report was argued and the benefits of its publication and the opportunities for reporting entities were outlined. The purpose of this document is to support the development of an International Integrated Reporting Framework that would meet the needs of the investor community as the primary audience for Integrated Reporting. As stated in this document, "Integrated Reporting brings together the material information about an organization's strategy, governance, performance and prospects in a way that reflects the commercial, social and environmental context within which it operates. It provides a clear and concise representation of how an organization demonstrates stewardship and how it creates value, now and in the future. Integrated Reporting combines the most material elements of information currently reported in separate reporting strands (financial, management commentary, governance and remuneration, and sustainability) in a coherent whole, and importantly:

- shows the connectivity between them; and

- explains how they affect the ability of an organization to create and sustain value in the short, medium and long term" [International Integrated Reporting Committee, 2011, p. 6].

Taking into account an enormous amount of time and effort used to prepare an Integrated Reporting framework, it is reasonable to ask about the probability of its acceptance by business practitioners. For this purpose, in 2011 IIRClaunched Pilot Programme Business Network which over 80 businesses from all over the world. This programme is designed to assist the IIRC in the development of the Integrated Reporting framework by testing the principles and practicalities of IR. In 2012 IIRC launched its next programme - Pilot Programme Investor Network, which purpose is to provide an investor's perspective on the shortfalls of current corporate reporting, provide constructive challenge and feedback on emerging reporting from Pilot Programme reporting organizations and the International Integrated Reporting Framework being developed and engage with peers in the investor community on integrated reporting. 


\section{Results}

\section{Integrated Reporting in business practice}

Contrary to financial reporting, companies practice in CSR reporting is not long. Business reporting in the modern sense was implemented in 1970s and until now it has undergone many changes. Since 1973 financial statements have been drawn according to national laws, International Accounting Standards and American US GAAP standards. In 1980s and 1990s new business reports, i.e. Management Commentary, Intellectual Capital Statements, Governance and Remuneration and Environmental Reports emerged. Reports which would at the same time take into account the economic, social and environmental aspects of business activities were issued only after 1997, when J. Elkington [1997] presented his self-developed concept of triple bottom line. A few years ago companies began to take on a larger scale an initiative of the so-called Integrated Report publication.

Research on business reporting practices, which draw attention to the growing popularity of Integrated Reporting, which may imply major changes in business communications, are led by the world's largest consulting companies (e.g., the work of KPMG since 1993), institutions such as the World Bank, United Nations, European Commission, international accounting organizations (e.g. CIMA, and the Federation of European Accounting Experts).

Analysis of the reporting of CSR activities carried out by KPMG for the past 18 years clearly shows that it is becoming more and more common. In 1993, the percentage of companies reporting CSR among the 100 largest in the 34 countries (N100) surveyed was 12, in 2008 - 53, and in the last three years it reached the level of 64 . On the other hand, 18 years ago, the percentage of companies that published a report on CSR among the 250 largest companies in the world (G250) was negligible, while in the last year it stood at 95 [KPMG International, 2011, p. 7].

According to the same study, the largest number in the world of CSR reports is produced in accordance with the GRI's Sustainability Reporting Framework and Guidelines. Business practice confirms their utility. In 2011, the reports were drawn up by $69 \%$ of companies in the N100 group and $80 \%$ of the $\mathrm{G} 250$ group [KPMG International, 2011, p. 20].

Currently, in the vast majority of countries, CSR reporting as well as Integrated Reporting are issued on the voluntary basis. However, some investors and sustainability activists continue their call for mandatory Integrated Reporting. Undoubtedly, a certain force in pulling Integrated Reporting forward was South Africa with its first requirements for Integrated Reports for years commencing on or after 1 March 2010 from companies listed 
on the Johannesburg Securities Exchange (JSE). The driver for this was the King Code of Governance Principles for South Africa 2009 (King III) becoming a JSE listing requirement. King III recommends that organizations should adopt integrated reporting on an 'apply or explain' basis what means that they must issue the Integrated Report or explain why they are not doing so. Meanwhile, the highest degree of Integrated Reporting is practiced in Brazil, Germany, South Africa, Sweden and United Kingdom, therefore companies from these countries are recommended to continue to exercise leadership in order to help create a more sustainable global society [Eccles R.G. and Serafeim G., 2011].

The results of the interviews conducted for the European Commission (EC) have shown that many readers expect sustainability reports to be integrated with the financial statements [Wensen et al., 2011, p. 102]. They contend that the Integrated Reports provide a number of benefits but the barriers of their preparation cannot be ignored, which is undoubtedly a challenge to overcome for the reporting organization.

\section{Determinants and Implications}

A fairly large CSR and IR reports popularity, especially in developed economies and among companies with relatively high capital, those that are open to changes, innovations, and above all aware of social responsibility, is thanks to the opportunities offered by these reports:

- they allow organizations to demonstrate interest in the state of the environment, social issues and their employees;

- they contribute to the overall preparedness and taking action related to sustainable development;

- they strengthen transparency;

- they build and maintain trust in the environment, including increasing the attractiveness of the organization as an employer (attracting highly skilled workers), convince socially responsible contractors (building a socially responsible supply chain), create interest in socially responsible investors;

- they allow to get some feedback from the environment on the action taken;

- they make it possible to make comparisons reporting organization;

- they highlight the relationship between the financial and non-financial results achieved;

- they incite innovation and promote the learning of organization;

- they provide an opportunity to explore new opportunities to improve business processes and implement continuous business improvement programs, including the construction and exploitation of synergies through increased collaboration between different departments involved in the implementation of CSR strategies;

- they help to identify, understand and overcome threats. 
It should also be noted that in general CSR report are still not a perfect tool of transparent communication with their users. As in the majority of countries there is no obligation to publish information on CSR and hence the lack of legally binding regulations relating to CSR reporting standards. This makes preparers if CSR/IR reports include the scope, form and frequency of information voluntarily and therefore causes some weaknesses of this publications, i.e.:

- too large and fragmentary material is included in a variety of themed reports (financial and non-financial) hence it is difficult to find cause-effect relationships between ESG indicators and financial performance;

- not very significant issues of the company are reported, and the key questions to assessing the scope and nature of its social responsibility are ignored, the lack of reliable information about the errors and lapses is evident, the report shows only successes (so-called "greenwashing");

- financial and non-financial information of the company are not comparable;

- reports of individual companies are not comparable;

- due to the absence of guidance as to the quality of non-financial information and external verification of non-financial reports - these reports can serve only as a marketing device.

Integrated Reports can be the remedy for the complaint about the lack of consistency between the financial information included in the financial statements and non-financial information contained in their satellite reports as well as the imbalance between this information and the fragmentation of the information. It also implies a number of other benefits that are presented in Table 1.

Table 1. The implications of integrated reporting

\begin{tabular}{|l|l|}
\hline Benefits of integrated reporting & Challenge for reporting organizations \\
\hline $\begin{array}{l}\text { Stating the business strategy so users can } \\
\text { understand the essence of these plans } \\
\text { and where they will take the organiza- } \\
\text { tion. }\end{array}$ & $\begin{array}{l}\text { The inclusion of the social responsibility into } \\
\text { main corporate strategy. }\end{array}$ \\
\hline Showing targets and future performance. & $\begin{array}{l}\text { Meaningful insight into management's plans } \\
\text { and aspirations. }\end{array}$ \\
\hline
\end{tabular}




\begin{tabular}{|c|c|}
\hline Benefits of integrated reporting & Challenge for reporting organizations \\
\hline \multirow[t]{2}{*}{$\begin{array}{l}\text { The overall picture of financial achieve- } \\
\text { ments and social responsibility (environ- } \\
\text { mental, social and corporate governance } \\
\text { issues). }\end{array}$} & $\begin{array}{l}\text { Integrated thinking about all the activities } \\
\text { of the company. It is necessary to change the } \\
\text { mentality of managers. Policy makers need to } \\
\text { understand the need to act in accordance with } \\
\text { social responsibility, include it in the company's } \\
\text { strategy as well as convince and involve all } \\
\text { employees. }\end{array}$ \\
\hline & $\begin{array}{l}\text { Integrated Reports should reflect meaningful } \\
\text { interaction and engagement with stakehold- } \\
\text { ers, filtering to material issues and demon- } \\
\text { strating responsiveness in the business strat- } \\
\text { egy and ultimately performance. }\end{array}$ \\
\hline \multirow{3}{*}{$\begin{array}{l}\text { Clear and coherent view of success, } \\
\text { shortcomings and challenges businesses } \\
\text { face that let to understand how manage- } \\
\text { ment is dealing with these issues. }\end{array}$} & $\begin{array}{l}\text { Balance between financial and non-financial } \\
\text { information. }\end{array}$ \\
\hline & $\begin{array}{l}\text { Use of all proper metrics for measurement of } \\
\text { quantitative information. }\end{array}$ \\
\hline & $\begin{array}{l}\text { Proper presentation of qualitative informa- } \\
\text { tion. Qualitative criteria need to consider } \\
\text { issues including reputation, credibility, sensi- } \\
\text { tivity and strategic relevance of matters. The } \\
\text { structure of a well-designed Integrated Re- } \\
\text { port provides a natural basis for determining } \\
\text { the material qualitative issues. }\end{array}$ \\
\hline $\begin{array}{l}\text { A basis for companies to explain their } \\
\text { value creation more effectively, espe- } \\
\text { cially to the capital markets. }\end{array}$ & $\begin{array}{l}\text { Appropriate connection between elements } \\
\text { of the report which leads to good linkage } \\
\text { and logical flow between financial and non- } \\
\text { financial information. Proper presentation of } \\
\text { cause-effect relationships between ESG indi- } \\
\text { cators and financial performance. }\end{array}$ \\
\hline \multirow[t]{2}{*}{$\begin{array}{l}\text { Material information useful for various } \\
\text { groups of investors. }\end{array}$} & $\begin{array}{l}\text { Identification of all financial and non-finan- } \\
\text { cial information needs of all stakeholder but } \\
\text { presentation only that are material for key } \\
\text { stakeholders. Selecting the right Key Perfor- } \\
\text { mance Indicators (KPIs) and placing them in } \\
\text { context. }\end{array}$ \\
\hline & $\begin{array}{l}\text { Application of the principle of continuity and } \\
\text { comparability. }\end{array}$ \\
\hline
\end{tabular}




\begin{tabular}{|l|l|}
\hline Benefits of integrated reporting & Challenge for reporting organizations \\
\hline $\begin{array}{l}\text { The ability to analyze the value chain and } \\
\text { the opportunities and important to it. } \\
\text { Reflection of strategy chosen by the or- } \\
\text { ganization to create and maintain share- } \\
\text { holder value. }\end{array}$ & $\begin{array}{l}\text { Proper identification of all areas of the organiza- } \\
\text { tion, the chain of values, as well as its chances } \\
\text { or risks. }\end{array}$ \\
\hline $\begin{array}{l}\text { Ensuring accountability for expenditures } \\
\text { on activities in the field of corporate social } \\
\text { responsibility and their effects. }\end{array}$ & $\begin{array}{l}\text { The designation of the person or unit respon- } \\
\text { sible for carrying out the process of social } \\
\text { responsibility and accounting of its costs and } \\
\text { benefits. Entering the purposes of corporate } \\
\text { social responsibility to the accounting processes } \\
\text { of management and recruitment. }\end{array}$ \\
\hline $\begin{array}{l}\text { Reliability of communication as a key } \\
\text { decision-making condition provided by } \\
\text { the reporting organization and its stake- } \\
\text { holders. }\end{array}$ & $\begin{array}{l}\text { A combined (internal and external) assurance } \\
\text { approach which needs to combine: } \\
\text { governance - oversight and approval of the } \\
\text { reporting strategy, structures and processes, } \\
\text { processes - establishment of appropriate } \\
\text { processes, systems and controls at all levels of } \\
\text { the integrated reporting process, including in- } \\
\text { ternal audit and external assurance providers, } \\
\text { data - assurance over quality of underlying } \\
\text { data, } \\
\text { use of judgment - assessments of risk and } \\
\text { materiality. }\end{array}$ \\
\hline $\begin{array}{l}\text { In the Integrated Report social and envi- } \\
\text { ronmental activities of the organization are } \\
\text { presented in such a way that these activities } \\
\text { seem to be important to the stakeholders, } \\
\text { so they promote themselves, and may even } \\
\text { encourage to them [Wensen et al. 2011, p. } \\
\text { 103]. }\end{array}$ & $\begin{array}{l}\text { Support from governments, the finance and } \\
\text { accounting community and wider stakeholder } \\
\text { proups in promoting the idea of integrated re- }\end{array}$ \\
\hline porting.
\end{tabular}

Source: Authors' preparation.

Supporters of Integrated Reporting argue that the inclusion of all material non-financial information into corporate reporting in a proper way would help steer business decision making in a more sustainable direction. They argue that the quality of reporting would improve because businesses would provide a more strategic picture of the issues that are critical to their long-term sustainability and success [Stevenson N., 2011].

Although Integrated Reports are beneficial to the organizations reporting, as well as to the business environment, it is noted that the transition from the existing reporting system into Integrated Reporting system will require a huge commitment from all market participants. 


\section{Final remarks}

Currently, business reports on various topics are more and more commonly used communication tool with the business environment; these reports are usually an addition to the mandatory financialstatements, but it's slowlystarting to change. Following the strategy of incorporating social responsibility into the overall enterprise strategy, Integrated Reports begin to emerge. According to the intentions of their creators they reflect all aspects of the unit in a given time and place - economic, social and environmental issues, already made, as well as intended to be implemented in the future. Therefore, they provide a sound basis for decision-making internally and by external stakeholders.

On the other hand extended business reporting poses great challenges for reporting staff and their stakeholders. Being aware of a number of Integrated Reporting benefits, every effort in development of this approach to companies communication is worth making. However, the success of CSR/ IR reporting depends on the co-operation of a wide range of participants from different disciplines within the business. Today enterprises are therefore on the way towards Integrated Reporting, consequently it is not a fad but a sign of future times and we may assume that one Integrated Reporting system of communication of companies that would support both internal management and external users; decisions is the goal for business units.

\section{Bibliography}

Bowen, H.R. (1953) Social Responsibilities of the Businessman, New York: Harper \&Row.

Cordazzo, M. (2007) 'IC Statement vs. Environmental and Social Reports: An Empirical Analysis of their Convergence in the Italian Context', in Zambon, S. and Marzo, G. (eds.) Visualising Intangibles: Measuring and Reporting in the Knowledge Economy, ASHGATE.

Deegan, C. and Rankin, M. (1997) 'The materiality of environmental information to users of annual reports', Accounting, Auditing and Accountability Journal, 10:4, pp. 562-583.

DiPiazza, S.A. and Eccles, R.G. (2002) Building Public Trust: The Future of Corporate Reporting, New York: John Wiley \& Sons.

Eccles, R.G. (2011) 'Perspective: the academic', Accounting Futures, Edition 03, ACCA, p. 14.

Eccles, R.G. and Krzus, M.P. (2010) One Report: Integrated Reporting for a Sustainable Strategy, New Jersey: John Wiley \& Sons.

Eccles, R.G. and Mavrinac, S. (1995) 'Improving the Corporate Disclosure Process', Sloan Management Review, Vol. 36, No. 4, pp. 11-25.

Eccles, R.G. and Serafeim, G. (2011) Leading and Lagging Countries in Contributing to a Sustainable Society, 23 May 2011, [Online], Available: http://hbswk.hbs.edu/ item/6716.html [7 Dec 2012]. 
Eccles, R.G., Herz, R.H., Keegan, E.M. and Phillips, D.M.H. (2001) The ValueReporting Revolution: Moving Beyond the Earnings Game, New York: John Wiley \& Sons.

Elkington, J. (1997) Cannibals with Forks: The Triple Bottom Line of 21st Century Business, Oxford: Capstone.

Epstein, M., Flamholtz, E. and McDonough, J. (1977) Corporate Social Performance, New York: National Association of Accountants.

Fijałkowska, J. (2012) 'Społeczna odpowiedzialność wyzwaniem dla rachunkowości', Przedsiębiorczość i Zarzq̨dzanie, Vol. XIII, Issue 1, pp. 141-154.

Gordon, L.A. (ed.) (1978) Accounting and Corporate Social Responsibility, The University of Kansas, Kansas: Lawrence.

Gray, R. (1990) The Greening of Accountancy: The Profession After Pearce, Certified Record Report 17, London: ACCA.

Gray, R., Bebbington, J. and Walters, D. (1993) Accounting for the Environment, London: Chapman.

Guthrie, J. and Parker, L.D. (1989) 'Corporate Social Reporting: A Rebuttal of Legitimacy Theory', Accounting and Business Research, 9:76, pp. 343-352.

Guthrie, J. and Parker, L.D. (1990) 'Corporate Social Disclosure Practice: A Comparative International Analysis', Advances in Public Interest Accounting, JAI Press, Vol. 3, pp. 159-175.

Ijiri, Y. (1975) 'Theory of Accounting Measurement', Studies in accounting research, No. 10, Sarasota Fl., American Accounting Association.

International Integrated Reporting Committee, (2011) Towards Integrated Reporting. Communicating Value In the 21st Century.

KPMG International, (2011) International Survey of Corporate Responsibility Reporting 2011.

Mathews, M.R. (1997) 'Twenty-five years of social and environmental accounting research. Is there a silver jubilee to celebrate?', Accounting, Auditing \& Accountability Journal, 10:4, pp. 481-531.

Matten, D. and Moon, J. (2008) “'Implicit” and “Explicit” CSR: A Conceptual Framework for a Comparative Understanding of Corporate Social Responsibility', Academy of Management Review, Vol. 33, No. 2, pp. 404-424.

Roberts, R.W. (1992) 'Determinants of corporate social responsibility disclosure: an application of stakeholders theory', Accounting, Organizations and Society, 17:6, pp. 595-612.

Sobczyk, M. (2013) 'Koncepcja społecznej odpowiedzialności a praktyka polskich przedsiębiorstw', Zarządzanie i Finanse. Journal of Management and Finance, Rok 11, Nr 1, Część 3, pp. 349-361.

Stevenson, N. (2011) 'New Dawn for Reporting', Accountancy Futures, ACCA, Edition 03, February, p. 11.

Sułkowski, Ł., The problems of epistemology of corporate culture, Journal of Intercultural 
Management, Vol. 1, No. 1, April 2009.

Wensen, K. van, Wijnand, B., Klein, J. and Knopf, J. (2011) The state of play in sustainability reporting in the EU.

Whitley, R. 1997 'Business systems', In Sorge, A. and Warner M. (eds.) The IEBM handbook of organizational behavior, London: International Thomson Business Press, pp. 173-186. 